\title{
計測によろ人の菌列(瀕模型)の性別判定法
}

\author{
田中戥策

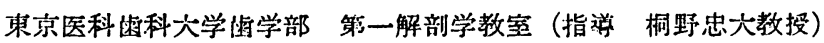 \\ (昭和 36 年 1 月 26 日受付)
}

\section{Sexual diagnosis of the human dentition by measurements}

\author{
Seisaku Tanaka \\ Department of Anatomy, Tokyo Medical \& Dental University. \\ (Director: Prof. Tadao Kirino)
}

\section{緒 論}

霊長類の歯の性差は，猿，類人猿では著明にみ とめられ，そのため個体の性別判定には欠くこと の出来ない要素とされているのである(図 1)。し からば人の歯では性差がみとめられるかどうかと いう問題が当然起つてくるのであるが，歯の計測 からこの問題の解明にあつた人々には Schaaffhausen $(1883,1884)$, Parreidt(1884, 1926), Mijsberg, (1931), 山田 (1932), 永峯 (1933)，滰口 (1941), Pedersen (1949), 大仹 (1957), 青山他 (1957)，権田(1959)等がある。これらの人々の取 り扱つた材料の数, 硎究対象を报去画にしたか, 頭藍に植立した齿か，或いは顎模型の上で計測し たかという違いはあるにしても, 夫々を群として すなわち男性群, 女性群として人のそれぞれの歯 の大きさを比較した場合に，平均值としては男女 間に性差がみとめられている。一方歯の形におけ る性差については, 猿, 類人猿では永久歯列の上下 顎犬歯および下顎第 1 小囦歯においては著明な性 差がみとめられる(図 2)，しいし人の歯では個体 の性別を判定するだけの形態上の特色が全くない といっても過言ではない。
歯列弓の形，大きさという問題についても個々 の歯の性差の場合と同様，男女それぞれの群に分 けられ測度の平均値を比較した場合にのみ性差が みとめられるに過ぎない。

あらかじめ性差のはつきりした男女の顎模型を それぞれくらべてみた時, 前者の方は後者のもの よりもやや男性的らしく, 後者のものが前者より もやや女性的らしいと思われるのみで，男性また は女性としての判别点を正確に知ることは出来な いのである。

このような次第で歯列月の観察或いは計測から 特別の判定を行う試みはいまだなされていないの である。しかし，歯列弓および歯の大きさ，形よ り男女の性别を判定することが出来れば人類学的 のみならず法医学的な方面にも大いに応用される 面があろうと思われる。

それで研究対象として顎模型を用い歯冠および 歯列弓の種々の径を計測して, その計測值から性 別を判定しようとしたのがこの論文である。

\section{材料, 計測項目}

計測に使用された材料は新潟近郊の高等学校の 男女生徒 (15 18 歳) より得られたものそれぞれ 

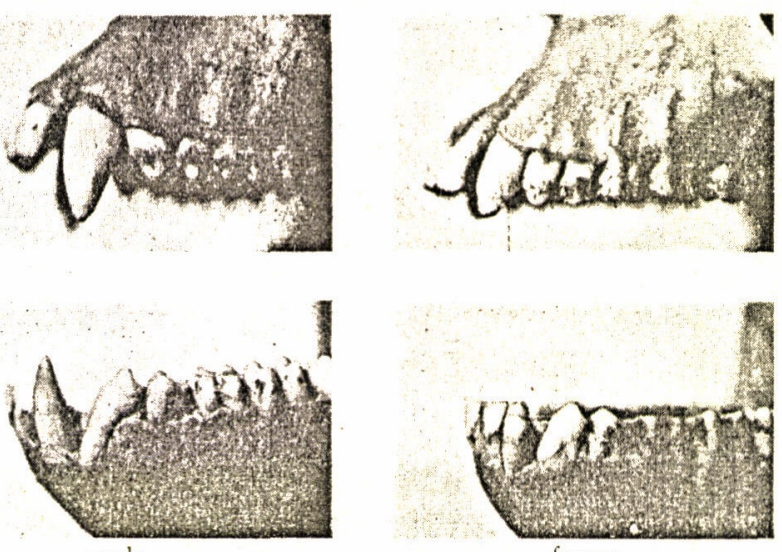

male

femae

Fig. 1 Sexual dimorphism in the macaque's dental row

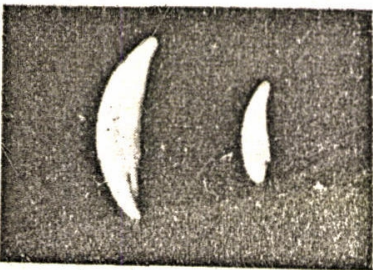

り出ていることをさすのである。

顎模型はあらかじめ充分清掃された口腔の印象

upper canines

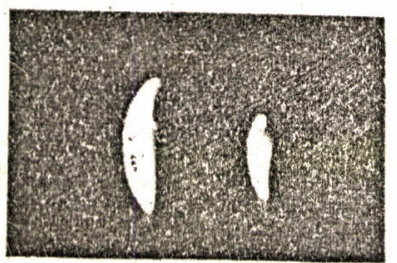

交弾性印象材(テクニコール)で採得し，こ机から

硬石高による模型をつくつたものである。

次ぎに計測項目についてであるが，この項目の 撰定は充分に意を用いる必要がある。その条仵在 示めすと,

1）撰定された計測項目が万人に共通して容易 に，かつ正確に計測しうるものであること。

2）当該項目の平均值においてかなり高い性差 がみとめられるものであること。

3）それらの項目は環境による影響をうけがた く，かつその形態が安定性を示めしていること。

4)・咬耗，磨耗言の他による二次的な影響をう

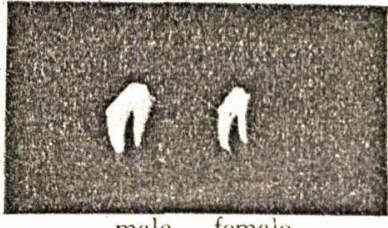

male femaie

Fig. 2 Sexual dismorphism of the macaque's teeth 100 個体分である。この年齢層のものは歯の疾患 にかかる率が未だ割に少なく，また咬耗，磨耗に よる歯質の欠損が少ないので計測の対象としては すぐれている。しかし歯の萠出が未だ完了してい ないという久点があるので，明らかにそれとわか る著明なものはすべて排除することとした。ここ でいう歯の萠出とは歯冠の最大膨隆部が歯肉縁よ
けることの少ないという項目であること等であ る。

個々の歯について，以上の諸条件在考え合わせ かつまた権田の成績を参照した場合, これらの目 的を達するためには正確に採得した完全な歯列を 有寸る若人のものの顎模型が適している亡思われ る。しかし権田のように計測項目を多数採用する 必要はない。

研究対象は顎の石膏模型であるので，歯の計測 はすべて歯冠部のみに限られる。通常歯冠部の㖕 測項目としては, 冠長径, 近遠心径, 煩舌径がと られるが,これらの項目のうちで, 冠長は私の研 究対象年龄層は若年者のため歯の歯頸線は完全に 
歯肉線より出ていないため正確に測定することが できない。そしてまた，近遠心径は隣在歯との接 触のためこれも計測が満足に行われないので結局 歯の計測項目としては煩舌径が利用されたに過ぎ ない。

なおまた歯種の面から考えると，上下第 2 小曰 㐘は萠出途上にあり，かつ退化的な歯であるこ と，更に下顎第 1 小臼歯は藤原(未発表)の調査に よればその形が恒常性を保つ率が変動して一様で なく，種々の形をとることが多いのでこれらの小 臼歯は研究対象からはずされた。煩舌径を各歯に ついて計測したところ平均値において著明な性差 のあるのは上下顎の犬歯，第 1 小臼㐘，および第 1 大臼蒾である。な掞第 1 大臼歯の近心半と遠心 半を比べると, 近心半の方が形態的に安定してい るが，遠心半はかなり不安定であるために煩舌径 の测定には近心半のもののみを採用することにし た。

歯列弓の測度については歯列弓幅のみとしこれ を第 1 大臼歯間で行うことにした。これは藤田， 仿伯の双生児の歯列弓の形態の研究より左右の第 1 大臼歯間幅は第 1 小臼歯間幅よりも遺伝的に安 定度が高いということによつた。なお氏等の研究 によれば上顎の歯列弓の諸径は下額のそれらより も形態的に安定度が高いということと，あとでの べるこの研究の性質上出来うる限り相関度の低い 項目を選ぶ必要があるので，計測のために撰定さ れる項目はすべて上顎のもののみに限られた。

以上の撰定された項目をまとめてみると，
A. 上顎犬歯の煩舌径。
B. 上顎第 1 小臼歯の煩舌径。
C. 上顎第 1 大臼歯の近心煩舌径。
D. 上顎第 1 大臼歯間の歯列弓幅である。 計測方法を列記すると，

A. 上顎犬歯の煩舌径は舌側の最大膨隆部に， ギスの 1 脚を接触させて, 遠心隣接面よりみて, その脚と遠心切縁の方向が平行になるようにして 他の脚を煩側の最大膨隆部にあてる。この時, 煩 側面の側の㑢が犬歯の煩側面に正確に接触しない 湯合にはこの材料を除いた。
B. 上頡第 1 小臼歯の煩舌径はノギスの 1 脚を 舌側面にあてて，歯冠軸の方向と平行になるよう に他の脚を煩側面にあてる。

C. 上頷第 1 大臼菌の近心煩舌径はノギスの両 脚を歯冠近心小简と遠心小窩を結んだ線に平行に なるようにして测定した。

C. 上顎第 1 大臼歯間の歯列弓幅はノギスの両 端をそれぞれ第 1 大臼歯の煩側面溝にあつて大白 歯の近心煩側部の最大膨隆部が両脚の間にあるよ うにして測定した。これらの計測には $1 / 20$ の幅尺

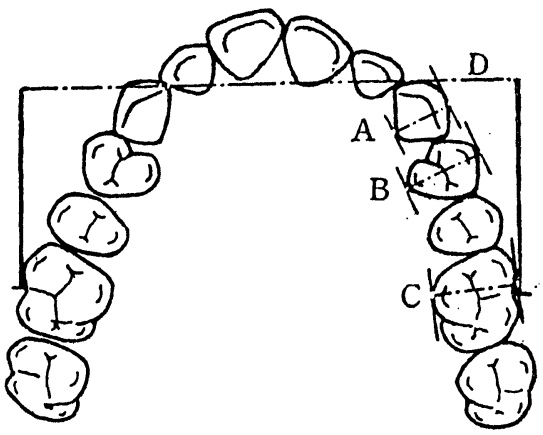

Fig. 3 Methods of measurement

のついたノギスを用い，A.からC. までの計測は 原則として左側のものについて行つた(図 3)。 以上の計測項目が同一個体の上顎影模型について 完全に行わ机た個体数は男性 59，女性 74 個体で ある。

\section{計 測成 績}

上述の計測項目の男女の平均值を比較すると （表 1），各項目ともに男性の方が女性より大きく かつ有意な差がみとめられる。これを権田の計測 值と比較すると各項目ともに権田のものと多少の 違いがある。これは材料の違いと計測方法による 違いで, 性差のあるという点については全く同じ 結果である。表 1 における各項目の齐却限界値の 幅を男女について比較すると，可成り数值の上 で overlap がある。もし上述の項目の中で数值の overlap のない項目があればその計測項目を利用 して充分に男女の性別判定が行わ机るわけであ る。しかし実際にはそのような項目が全くみられ ないので, 各項目の計測値にある程度の重みづけ 
Table 1 Results of measurement (unit : mm)

\begin{tabular}{|c|c|c|c|c|c|c|c|c|}
\hline & \multicolumn{4}{|c|}{ Male } & \multicolumn{4}{|c|}{ Female } \\
\hline & \multicolumn{4}{|c|}{ Number of Materials 59} & \multicolumn{4}{|c|}{ Number of Materials 74} \\
\hline Item & A & $\mathrm{B}$ & $\mathrm{C}$ & $\mathrm{D}$ & A & $\mathrm{B}$ & C & $\mathrm{D}$ \\
\hline Mean & 8.51 & 9.61 & 11.31 & 60.40 & 8.00 & 9.28 & 10.91 & 57.30 \\
\hline $\begin{array}{l}\text { Standlard } \\
\text { Deviation }\end{array}$ & 0.505 & 0.537 & 0.458 & 2.233 & 0.495 & 0.514 & 0.531 & 2.489 \\
\hline $\begin{array}{l}\text { Rejection } \\
\text { Intervals }\end{array}$ & $\begin{array}{r}8.94 \geqq \mathrm{x} \\
\geqq 8.08\end{array}$ & $\begin{array}{r}10 .(17 \geqq \mathrm{x} \\
\geqq 9.15\end{array}$ & $\begin{array}{l}12.55 \geqq \mathrm{x} \\
\geqq 10.07\end{array}$ & $\begin{array}{r}66.45 \geqq \mathrm{x} \\
\geqq 54.35\end{array}$ & $9.31 \geqq \mathrm{x}$ & 10. $64 \geqq x$ & $\begin{array}{r}12.32 \geqq x \\
\geqq 9.50\end{array}$ & $\begin{array}{r}63.91 \geqq x \\
\geqq 5(0.69\end{array}$ \\
\hline
\end{tabular}
A : Bucco-lingual dimension of upper canine
B : Bucco-ligual dimension of -upper first premolar
C: Trigone breadth of upper first molar
D : Dental arch width measured between upper first molars

をして綜合的に性別を判定する以外に方法はない のである。

1936, Fisher は多項目の測定より2群を判別す るための判別函数式を導いた。この方法の原理は いくつかの測定値を用い，その各々の值に適当に 重みうけけをしたで一次式に台成する方法であ る。そしてその重みづけすなわち判別係数は 2 群 を最もよく判別するように定められる。Fisher は この判別函数式を分類学上の問題のために導いた のであるが，単に分類ばかりではなく所属不明の 個体をどの群に属させればよいかという方面につ いても広く応用さ机うる性睤のもりである。

この論文は Fisher の判別函数式を利用した時, 歯列からどの位正確に男女の别を判定し得るかを 検討したものである。判別函数式はその性質上， 相関の高い測定項目を用いても無意味であるの

Table 2 Correlation Coefficients among Items

\begin{tabular}{ll|c|c|c|c}
\hline & & A & B & C & D \\
\hline A & $\begin{array}{l}\mathrm{m} . \\
\mathrm{f} .\end{array}$ & & & & \\
& & & & \\
$\mathrm{B}$ & $\mathrm{m}$. & 0.3356 & & & \\
& $\mathrm{f}$. & 0.5289 & & & \\
$\mathrm{C}$ & $\mathrm{m.}$ & 0.3019 & 0.5244 & & \\
& $\mathrm{f}$. & 0.4938 & 0.6439 & & \\
$\mathrm{D}$ & $\mathrm{m}$. & 0.3227 & 0.3578 & 0.4833 & \\
& $\mathrm{f}$. & 0.2392 & 0.3861 & 0.3736 &
\end{tabular}

m. : Male f. : Female
Table 3 Differences between means of both sexes

\begin{tabular}{c|c|c|c|c}
\hline Item & $\mathrm{A}$ & $\mathrm{B}$ & $\mathrm{C}$ & $\mathrm{D}$ \\
\hline Male-Female & 0.51 & 0.33 & 0.40 & 3.10
\end{tabular}

(unit : mm)

Sum of Squares and Sum of Products for each Items

\begin{tabular}{c|r|r|r}
\hline $\mathrm{Sij}$ & \multicolumn{1}{|c|}{ Nale } & \multicolumn{1}{c|}{ Female } & \multicolumn{1}{c}{ Total } \\
\hline $\mathrm{S}_{\mathrm{AA}}$ & 15.0176 & 18.1175 & 33.1351 \\
$\mathrm{~S}_{\mathrm{AB}}$ & 5.3652 & 9.9585 & 15.3237 \\
$\mathrm{~S}_{\mathrm{AC}}$ & 1.1181 & 9.6100 & 13.7281 \\
$\mathrm{~S}_{\mathrm{AD}}$ & 21.0799 & 21.7975 & 42.8774 \\
$\mathrm{~S}_{\mathrm{BB}}$ & 17.0199 & 19.5711 & 36.5910 \\
$\mathrm{~S}_{\mathrm{BC}}$ & 7.6158 & 13.0239 & 20.6397 \\
$\mathrm{~S}_{\mathrm{BD}}$ & 24.8839 & 36.1940 & 61.0779 \\
$\mathrm{~S}_{\mathrm{CC}}$ & 12.3879 & 20.9040 & 33.2919 \\
$\mathrm{~S}_{\mathrm{CD}}$ & 28.6784 & 36.5736 & 65.2520 \\
$\mathrm{~S}_{\mathrm{DD}}$ & 294.2201 & 458.4620 & 752.6821 \\
& & &
\end{tabular}

で, 出来るだけ相関の低いものを選ぶ必要がある。 ここに用いた計測項目における項目間での相関係 数は表 $2 に$ 示寸通りで，一般に比較的相関が低い と思われる。しかし常識的に各項目間で全然相関 関係がないという性質のものではない。

判別函数式の算出に関する理論注成書に中うる 
こととして，ここで私の各項目についての男女両 群の平均値差, 変動および共変動 (sij) を表にまと めた(表 3 )。

各項目それぞれに関する変動和と共変動和およ び平均值差から次の 4 つの連立方程式がつくられ る。

$$
\begin{gathered}
33.1351 \mathrm{a}+15.3237 \mathrm{~b}+13.7281 \mathrm{c} \\
+42.8774 \mathrm{~d}=0.51 \\
15.3237 \mathrm{a}+36.5910 \mathrm{~b}+20.6397 \mathrm{c} \\
+61.0779 \mathrm{~d}=0.33 \\
13.7281 \mathrm{a}+20.6397 \mathrm{~b}+33.2919 \mathrm{c} \\
+65.2520 \mathrm{~d}=0.40 \\
42.8774 \mathrm{a}+61.0779 \mathrm{~b}+65.2520 \mathrm{c} \\
+752.6821 \mathrm{~d}=3.10
\end{gathered}
$$

式中の $\mathrm{a}, \mathrm{b}, \mathrm{c}, \mathrm{d}$ は上顎犬歯煩舌径 $\mathrm{A}$, 上额籘 1 小曰歯煩舌径 $\mathrm{B}$, 上顎第 1 大臼歯近心煩舌径 $\mathrm{C}$, 背列弓幅 $\mathrm{D}$ に対応する係数である。この連立方程 式から各系数をもとめて一次の形にすると

$\mathrm{Y}=0.0111 \mathrm{~A}-0.0028 \mathrm{~B}+0.002 \mathrm{C}+0.0036 \mathrm{D}$ となる。

この式によつて男女雨群における判別值の平均 をそれぞれ求めると次の通りである。

$\mathrm{Y} \hat{\delta}=0.309875$

$\mathrm{Y}$ 우 $=0.293098$

これら両群の平均値の差を検討してみると $\alpha<$ 0.01 で有意の差がみとめられ，両群すなわち男 性，女性のそ机ぞ机の群は全く性質の異つた集団 であることが分る。

以上のようにして雨群の判別値の平均値が得ら れるわけであるが，実際に性別不明の個体の顎模 型について A, B, C, D の 4 個の計測を行つてそ の属する群を判定するためには各項目に当該係数 を乘じてその和を求める。そしてその和 $\left(\mathrm{Y}^{0}\right)$ が

$$
\mathrm{Y}^{00}=[\mathrm{Y} \hat{0}+\mathrm{Y} \text { 宁 }] / 2=0.301487
$$

として定めた判別限界值 $\left(Y^{00}\right)$ より大きけ机ばそ の個体を男性のもの，それょり小さけ机ば女性の ものとして判定する。

次ぎにこの判別函数式を用いて個体の性別を誤 つて判定する率すなわち危険率は, 判別限界值と 耑群に方ける判別值の平均値との差を判別值の標
準偏差 $\sigma \mathrm{y}$ で割つて基準化し，その h 值について $\operatorname{Pr}\{$ hl $\geqq \mathrm{t}\}=\alpha$ を計算すればよい。

このためには基準化正規分布の確率積分の表が 用いられる。くわしい方法は成書を参照すること にして，一応危険率を私の材料数から求めてみる と, $\alpha=0.2296$ となり, 性別の全く不明な個体の歯. 列を上述の 4 項目について計測し，私の判別函数. 式より性別を判定すれば，約 $80 \%$ (77\%) の適中 率で性別の判定が理論上可能となるわけである。 勿論 $\alpha=0.2296$ は私が使用した男 59, 女 74 個体. の材料と，上記の 4 項目によつて得られたもの で，材料数の增大，また項目数の増加，変更によ つて多少の変動はあると思わ狆る。しかし一見歯 列弓および菌冠の形において男女の識別が殆んど 不可能に近かつたものもこのような計測法を行う ことによつて， $80 \%$ 近く男女の 識別が 可能にな つたことははなはだ興味のある問題といわなけれ ばならない。

\section{考案}

人の歯列の計測，および観察から性別を判定し 得たという研究は従来行なわ机ていなかつた。そ 机で埴原(1958，1959)に扔ける骨の計測時の判別 函数式の成績をみてみると，一本の長骨を計測し た場合, 性別の判断を誤る率は精々 $10 \%$ 内外であ るといつている。また頭骨最大長，頭骨最大幅， 煩骨弓幅，上顔高の 4 項目による頭蓋における性 別判定は他の骨の各部の計測項目におけるよりも 成績が覀々危険率は $16.93 \%$ \%゙あるという。そし て頭蓋における他の計測項目のいくつか組合せに よる測別判定の的中县の平均は $90 \%$ 弱であると いつている。

観察を主として頭蓋の性別判定を行つた時熟練 した人で $95 \%$ 位の的中率をうることが 可能であ る (Hrdlička[1939]) といわれているが，それに 対する埴原の 判別函数式の的中率約 $90 \%$ と私の 得た的中率約 $80 \%$ とを比較した場合, 歯列に掞い ては上述したように形の上で性別を判定し得るに たる特徵を掝み得ないということから考え合せて みると, 歯列上の僅か 4 項目の計測から思春期に 
やつと達したと思われる若年者の性別判定をある 程度なし得るということは可成り有効な手段とい われなければならない。

なお，私の計测項目のうち上影犬蔽の煩舌径は 煩舌それぞれの最大膨隆部間で行われ得たかは年 㱓的にみて一層㭘討する余地があり，上記の計測 方法をさらに高年者によつて確かめたいと考えて いる。

\section{結 論}

著者は性別不明な顎慔型について，上顎犬歯お よび第 1 小臼歯の煩舌径，上頢第 1 大田歯の近心 煩舌径，さらに歯列弓幅を第 1 大目歯間で測定す る 4 項目より性別を判定するために判別函数式を 導いた。この計測項目および判別函数式によれば 形態上全く性別の特徵を㨔み得なかつた顎模型に おいて約 $80 \%$ の的中率で性別を判定し得る。こ の際の危険率 $\alpha=0.2296$ は例数の増大, 計测項 目の改良によつてさらに改善されよう。そして苗 列弓の計測により性別を判定し得るということは 人類学上また法医学上ははなはだ重要なことと 考えられる。

\section{交献}

1) Fischer, R. A. : 1936, The use of multiple measurements in taxonomic problems, Ann. Eug., 7, 179-188.

2) Fisher, R. A. : 1950, Statistical methods for research workers, 11 th ed., London,

3) Hrdlicka, A. : 1939, Practical anthropometry, 2 nd. ed., Philadelphia,

4) Mijsberg, W. A. : 1931, On sexual difference in the teeth of the Javanese, Kon. Ak. Westenschffen to Amsterdam, Proc. Sec. Sciences, 34, 1111-1115.

5) Parreidt, J. : 1884, Die Breite der oberen zentralen Schneidezähne beim männlichen und weiblichen Geschlect, D. Mschr. Zahnhlkd., 2, 191-196.

6) Parreidt, J. : 1886, Sind die mittleren oberen Schneidezähne bei der Frau absolut oder verhältnismassig breiter als beim Manne und wa. chsen die Zahnkronen nach der Verördung des Schmelzorganes noch in die Breite? D. Mschr. Zahnnlkd., 4, 203-213.

7) Pedersen, P. O. : 1949, The east greenland eskimo dentition. Kopenhagen.
8) Schaaffhausen, A. : 1883-84, Über die Kronenbreite der oberen mittleren Schneidezähne des Menschen. Coor-Bl. Dtsch. Ges. Anthr., Ethn. u. Urgesch., 14, 112-114; 15, 95-96.

9) Seipel, C. M. : 1946, Variation of tooth position. Svenk Tandl. Tiskr., 39.

10）青山敏男・松本清・小林徳之助・松田隆雄：1957, 日本人個体齿の大きさの性別的差異について， 蒲科医学, 20, 344-353.

11）藤田恒太郎：1948, 歯の計測規準について，人 颣学架誌, 61, 1-6.

12）藤田恒太郎：1949, 菌の解剖学， 3 版，金原出 版, 東京.

13）藤田恒太郎・佐伯政友：1961，双生児法による 歯列形態の遗伝学的吥究, 双生児吥究 III.

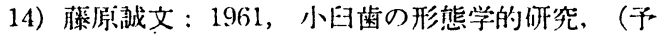
定).

15）権田和良：1959，画の大きさの性差について， 人類学雑誌, $67,151-163$.

16）埴原和郎：1958, 别别函数に上る日本人坦骨の 性別判定法, 人颣学雑誌，66, 187-195.

17）埴原和郎：1959，判別函数に上る日本人頭高な らびに有甲骨の性別判定法，人類学雑誌，66, 191-195.

18）片山宏: 1958, 咬合菌列马, 口盖の形態学的研 究, 蔽科学報, 58,1 号付録, 1-21.

19）黑沢佳太郎：1956，歯列弓の形热に関寸る胡測 学的研究, 画科月報, 29, 261-274.

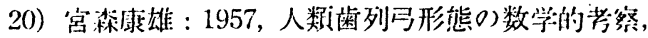
歯科医学, 20, 439-443.

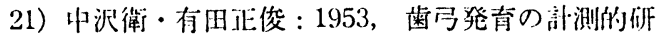
究, 蒾科医学雑誌 ( 5 回), 113-115.

22）大䡒徽: 1959 , 永久歯菌冠掞よび菌列形態の家 族的傾向に関する研究, 補緅学会誌，3，153174.

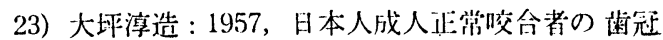
幅径上画列弓义び Basal arch 上の関係心つい て, 矮正学会誌, $16,36-46$.

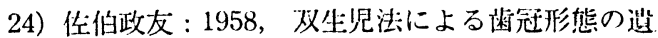
伝の研究，解剖学雑誌，33，456-470.

25）任藤举雄：1937, 邦人菌宁並び身体各部発有の 比例的研究, 歯科学雑誌, 30 .

26）佐藤笔雄・秋山良三：1937, 歯弓並びに口蓋大 さの比例的㼋究, 歯科学雑誌, 30 .

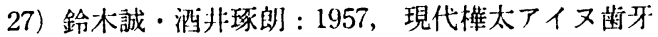
及び口腔の形態学的研究, 人類学輯報, 18. 303 -346 .

28）流口源三郎：1933, 齿牙形態各部の比例的関係 に就きて, 带科学推誌, $20,37-42$.

29）滰口源三郎：1941，芷の大きさに関する男女の 差, 歯科月報, $21,221-223$.

30）山田越二：1932, 日本人歯牙の人種解剖学的研 究, 歯科学篗誌, 25, 634-727. 